\title{
A QUANTITATIVE SAMPLING METHOD FOR ASSESSMENT OF DEEP CRYPTOBENTHIC ICHTHYOFAUNA USING TRIMIX DIVING
}

\author{
Igor GLAVIČIĆ ${ }^{1}$ and Marcelo KOVAČIĆ ${ }^{* *}$ \\ ${ }^{1}$ Department of Marine Studies, University of Split, Split, Croatia \\ ${ }^{2}$ Natural History Museum Rijeka, Rijeka, Croatia
}

Glavičić I., Kovačić M. 2016. A quantitative sampling method for assessment of deep cryptobenthic ichthyofauna using trimix diving. Acta Ichthyol. Piscat. 46 (1): 43-47.

\begin{abstract}
The first quantitative sampling method for deep cryptobenthic and epibenthic ichthyofauna using trimix diving was performed at about $60 \mathrm{~m}$ depth at two localities off the island of Hvar (eastern central Adriatic Sea) in October 2014. The safe, efficient, and relatively simple diving technique combined with the quantitative method for collecting fishes on studied depths is described and explained. A total of 16 fish specimens representing four species, i.e., three gobiid and one blenniid species, were collected using anaesthetic quinaldine at six bottom quadrats (squares) of $1 \mathrm{~m}^{2}$. The cryptobenthic and small epibenthic ichthyofauna on these habitats at circalittoral depths could not be efficiently sampled by any other method. Two of the collected species, Thorogobius macrolepis (Kolombatović, 1891) and Vanneaugobius dollfusi Brownell, 1978, are considered rare with very few reported records. The deepest findings of species Parablennius rouxi (Cocco, 1833), Gobius auratus Risso, 1810, and T. macrolepis were recorded.
\end{abstract}

Keywords: circalittoral zone, deep diving, Mediterranean, quadrat sampling, rare fishes, deepest records

During the second half of the 20th century, in situ observation and collection of fishes reached circalittoral bottoms like tropical mesophotic coral ecosystems (Bejarano et al. 2010), most often using research submersibles. However, due to their high cost, submersibles were in general used in the research of deeper habitats, rather than circalittoral depths, and their use to study bottoms at depths of 40-200 m has remained rare (Thresher and Colin 1986, Dennis and Bright 1988). Later, near the end of the 20th century remote operated vehicles (ROVs) became more widely used, but they were greatly limited in their ability to collect specimens (Pyle 1998). The advance of diving techniques at the turn of the century enabled not only observations and visual census of circalittoral ichthyofauna by divers (Brokovich et al. 2008, Bejarano et al. 2010), but also collection of fish specimens. However, studies using SCUBA diving for collecting fishes at marine reefs going deeper than $40 \mathrm{~m}$ are rare and restricted to the Western Atlantic and Pacific (Feitoza et al. 2005 to $70 \mathrm{~m}$ of depth, Pyle 1999 and his references therein to $150 \mathrm{~m}$ of depth, Pyle et al. 2008 to $120 \mathrm{~m}$ of depth). The primary goal of these researchers was to get samples for species identification i.e., qualitative data on species presence for results in biodiversity, biogeography and systematics by erratic collecting of fishes (Pyle 1998).
Destructive methods using SCUBA diving and ichthyocides or anaesthetics for quantitative studies on cryptobenthic fish communities are less frequently used and usually restricted to shallow depths, and no published research with quantitative data on cryptobenthic fish has been performed at or below $40 \mathrm{~m}$ of depth (Kovačić et al. 2012). One still unpublished slightly deeper quantitative research is the recently submitted work of the present authors from the locality Smočiguzica with a sampling of 50 bottom quadrats (squares) performed at depths of 15-45 m between June and October 2013.

The problem with diving at greater depths is that such diving is associated with a possibility of developing decompression sickness and with problems related to breathing gases causing nitrogen narcosis and oxygen toxicity. Consequently, using compressed air at greater depths for collecting is not just a safety problem, but it influences collecting methods and procedures by a lower level of accuracy and precision of obtained data, primary because of the narcotic effect of nitrogen. Therefore, a breathing gas mixture other than air has to be used. The present sampling was performed at depths between 57 and $62 \mathrm{~m}$ (Fig. 1), using trimix 20/30 as a bottom gas and nitrox 50 as a decompression gas (Van Rees Vellinga et al. 2006). Trimix enables safe diving at greater depths and nitrox enables a significant reduction of decompression

* Correspondence: Dr Marcelo Kovačić, Prirodoslovni muzej Rijeka, Lorenzov prolaz 1 HR-51000 Rijeka, Croatia, phone and fax: +385 51 553669, e-mail: (MK) marcelo@prirodoslovni.com, (IG) igor.glavicic@gmail.com. 
time (a 50\% reduction compared to decompression with compressed air) and also safer diving. We used double $12 \mathrm{~L}$ diving tanks connected with a manifold, 2 separate first stage diving regulators for trimix and a separate decompression tank of $11 \mathrm{~L}$ for decompression with nitrox. We also applied deep decompression stops prior to mandatory shallow stops (Pyle 1997) of 2 min starting from $30 \mathrm{~m}$ of depth. Nitrox was used as a tool to accelerate decompression stops and to decrease the risk of decompression sickness (Marinović et al. 2012). The change of breathing gases was performed at a depth of $21 \mathrm{~m}$, corresponding to $\mathrm{O}_{2}$ partial pressure in nitrox of 1.6 bar. The dives were performed following dive plans prepared in advance using V-Planner (SCUBA diving decompression planning software V-3.89) (Fig. 2), while the Mares Icon HD diving computer was used solely as a bottom timer.

The aim of the presently reported study was to introduce and test the use of trimix diving for quantitative studies of cryptobenthic and epibenthic fish communities of deep littoral bottoms i.e., of the circalittoral zone on the example of the Mediterranean. The method using diving and anaesthetics or ichthyocides is the only method in general that can ensure efficient collection of truly cryptobenthic fishes (Kovačić et al. 2012). It is also the only method that can be used to find and collect small epibenthic fishes on the rugose rocky and mixed bottoms.

The study was carried out during October 2014 in the area of the Hvar Channel, central eastern Adriatic. All sampling occurred during daytime, between 1400 and 1600 hours. The studied localities were two underwater steep reefs, called Smočiguzica $\left(43.2354^{\circ} \mathrm{N}, 16.573217^{\circ} \mathrm{E}\right)$, and Zala Luka $\left(43.3068^{\circ} \mathrm{N}, 16.441517^{\circ} \mathrm{E}\right)$, which are a part of the island of Hvar, but more than $200 \mathrm{~m}$ away from the coastline. Surfaces of both reefs consist of steep to vertical limestone bedrock surrounded by a sandy bottom. The base of the reefs is at a range of 57-62 $\mathrm{m}$ of depth, so that base area was chosen for the study as the deepest reef part.

Two divers, both experienced and skilled in diving and in fish and other marine species identification, performed each collection. The collecting protocol was modified from Kovačić et al. (2012) (Fig. 1):

- Visual census of the epibenthic fishes;

- Fixing a frame $(1 \times 1 \mathrm{~m})$ onto the cliff;

- Photographing the $1 \mathrm{~m}^{2}$ square as reference for the recheck of habitat parameter values assigned in situ;

- Recording habitat characteristics and the temperature in $1 \mathrm{~m}^{2}$;

- Spraying the anaesthetic into the square, catching escaping fishes with a scoop net and waiting for about $2 \mathrm{~min}$;

- Removing biocover and movable parts of the bottom structure and collecting anesthetised fishes.

The anaesthetic used was quinaldine diluted $1: 15$ with $96 \%$ ethanol and then mixed 1: 5 in $750 \mathrm{~mL}$ bottles with sea water (modified from Kovačić et al. 2012). Two bottles were usually used for each square i.e., the total volume

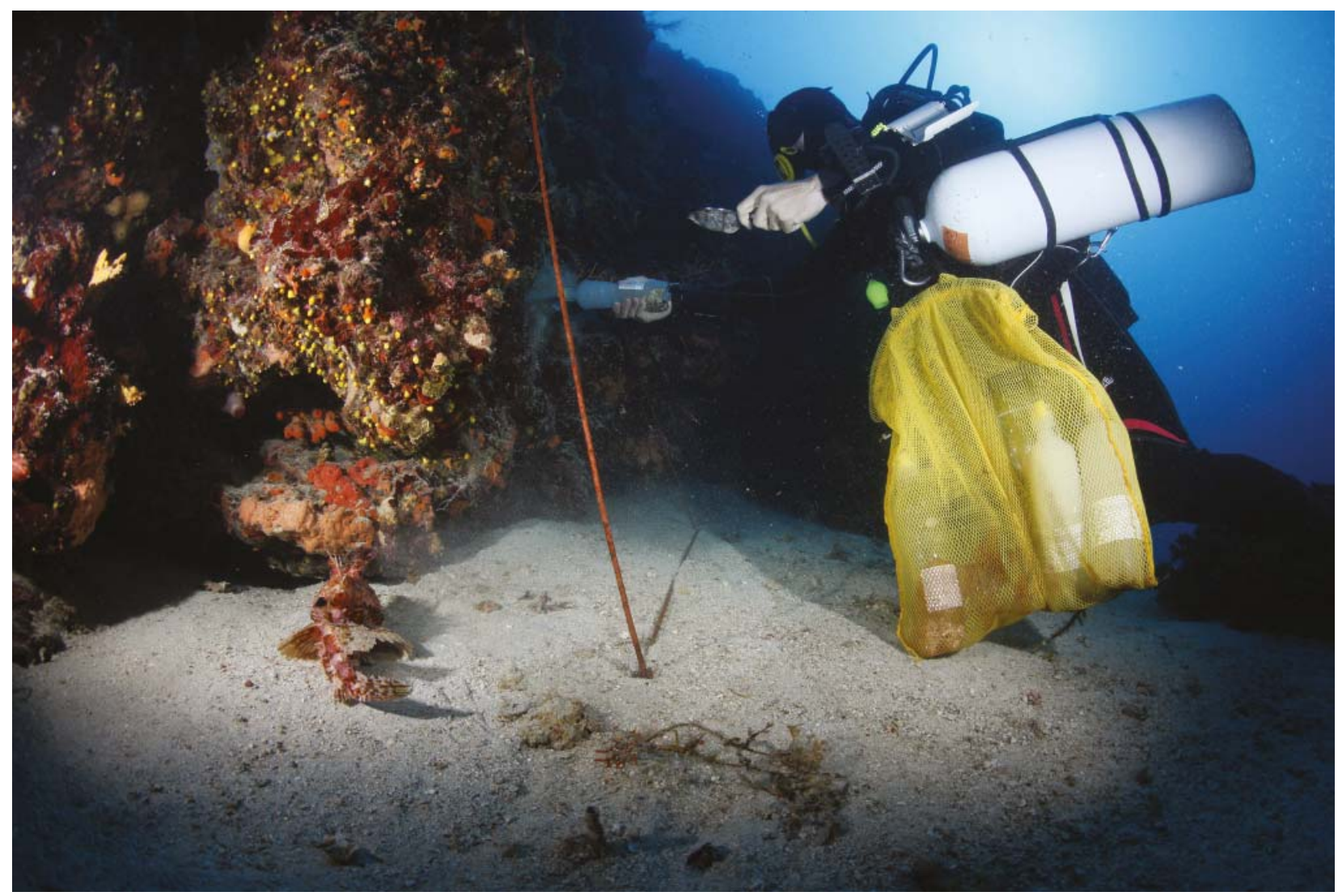

Fig. 1. Collecting within an iron bar quadrat with anaesthetics and small scoop net, depth 58 m, locality Smočiguzica; Photo by Dani Laslo 


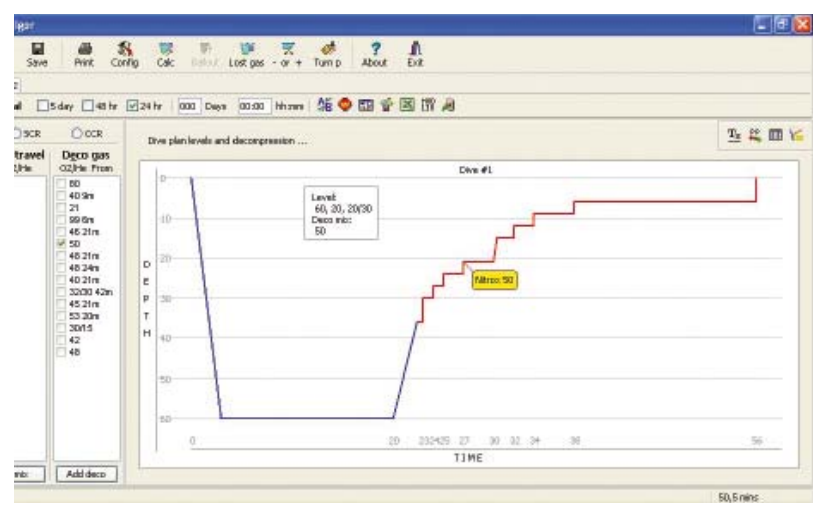

Fig. 2. The graph of the prepared dive plan for performed dives at $60 \mathrm{~m}$ of depth and used combination of breathing mixtures; Produced using V-Planner scuba diving decompression planning software and used for all present dives

of deployed quinaldine-ethanol solution was about 300 $\mathrm{mL} \cdot \mathrm{m}^{-2}$. The anaesthetic affected only the specimens within the square and only they were collected. No sea currents were present during the collecting, or in one case they were light, so sea currents have not influenced the diving and collecting procedure, including the use of quinaldine. All collected specimens were put to death after reaching the surface by a quinaldine overdose and stored in $65 \%$ ethanol solution. The preliminary field species identification of cryptobenthic specimens was later rechecked in the lab. All examined material has been deposited in the Natural History Museum Rijeka (PMR), Croatia.

At six bottom quadrats of $1 \mathrm{~m}^{2}$ a total of 16 fish specimens representing four species were collected using the anaesthetic quinaldine (4 species at Zala luka and 2 at Smočiguzica). In this number there were three gobiids: Gobius auratus Risso, 1810; Thorogobius macrolepis (Kolombatović, 1891); Vanneaugobius dollfusi Brownell, 1978; and one blenniid species: Parablennius rouxi (Cocco, 1833).

The fish assemblage in bottom quadrats was dominated by gobiid specimens, with just one individual belonging to a non-gobiid species, the blenny Parablennius rouxi. The most numerous species was Gobius auratus. However 7 specimens of this species were all found together as a school at the same quadrat. The more frequent ones were Thorogobius macrolepis with 5 specimens present at 2/3 of bottom quadrats and Vanneaugobius dollfusi with 3 specimens present at $50 \%$ of bottom quadrats. The mean total abundance of fishes in the bottom quadrats was $2.67 \pm$ 1.28 individuals $\cdot \mathrm{m}^{-2}$ (mean \pm standard error of the mean), but the distribution is heavily right-skewed ranging from 1 to 9 individuals $\cdot \mathrm{m}^{-2}$ with a median value of 1.5 and modal value of 1 . Some of the T. macrolepis and V. dollfusi specimens and the majority of the G. auratus specimens were observed before the application of the anaesthetic i.e., they were in an epibenthic position.

List of fishes collected: Gobius auratus: 2 males, $40.9+9.2$ and $49.0+11.3 \mathrm{~mm}$ (standard length + caudal fin length), 5 females, $33.0+8.8-40.6+9.9 \mathrm{~mm}$ (PMR VP3367), Smočiguzica, central eastern Adriatic, 8 October 2014.
Thorogobius macrolepis: 1 male, $33.8+8.0 \mathrm{~mm}$ (PMR VP3360), 1 female, $47.7+11.1 \mathrm{~mm}$ (PMR VP3361), Zala Luka, central eastern Adriatic, 2 October 2014; 2 males, $41.8+9.8$ and 47.7 + 11.6 mm (PMR VP3363), Zala Luka, central eastern Adriatic, 6 October 2014; 1 female, $43.8+$ $10.4 \mathrm{~mm}$ (PMR VP3365), Smočiguzica, central eastern Adriatic, 8 October 2014. Vanneaugobius dollfusi: 1 female, $25.2+6.5$ (PMR VP3362), Zala Luka Island, Hvar Channel; central eastern Adriatic, 6 October 2014; 1 female, 36.3 + 7.3 mm (PMR VP3364), 1 male, $36.1+7.0$ mm (PMR VP3366), Smočiguzica, central eastern Adriatic, 8 October 2014. Parablennius rouxi: 1 specimen of unidentified sex, 42.2 + 7.9 mm (PMR VP3368), Smočiguzica, central eastern Adriatic, 8 October 2014. All materials were collected by Igor Glavičić and David Pivalica.

The mixed bottom in studied quadrats was composed of bedrock and of muddy sand and gravel, consisting mostly of shell debris. The recorded biological communities in bottom quadrats belonged to the circalittoral zone. The coralligenous biocoenosis was developed on the bedrock, including the two variations of this biocoenosis: the facies of Eunicella cavolini and facies of Parazoanthus axinellae. At these depths no trace of biocoenosis of infralittoral algae existed on the bedrock. The coralligenous community consisted of species characteristic of this community: calcareous encrusting algae (Lithophyllum sp., Peyssonnelia rubra), other sciaphilic algae (Flabellia petiolata), and sessile invertebrates (Porifera, Cnidaria, Bryozoa, and Tunicata). The shell debris sediment had rarely scattered surface fauna of biocoenosis of coastal detritical bottoms like Cerianthus membranaceus. Hyperbenthic and larger epibenthic fish fauna around bottom quadrats was rare at these depths and it was represented by: Chromis chromis (Linnaeus, 1758); Phycis phycis (Linnaeus, 1766); Scorpaena scrofa Linnaeus, 1758; and Trigloporus lastoviza (Bonnaterre, 1788).

Vanneaugobius dollfusi was the only one among four recorded species occurring exclusively in circalittoral bottoms down to $160 \mathrm{~m}$ (Ahnelt and Dorda 2004). The presently reported finding at $60 \mathrm{~m}$ represents the deepest records of Parablennius rouxi, Gobius auratus, and Thorogobius macrolepis and shows these species for the first time as fishes with width-depth range i.e., infralittoral to circalittoral species. Thorogobius macrolepis was hitherto known as an infralittoral species with a depth range of 6-45 m (Ahnelt and Kovačić 1997, Francour et al. 2007). Gobius auratus also seemed to be limited to the infralittoral zone with maximum reported depths of $35 \mathrm{~m}$ (Herler et al. 2005) and $40 \mathrm{~m}$ (Francour et al. 2007). The published lower depth range of $P$. rouxi was $42 \mathrm{~m}$ (Zander 1986). Vanneaugobius dollfusi is known from only a few records. It was described at the Atlantic coast of Morocco, and two decades passed with only the type record known. It has been found again in the eastern Adriatic Sea (Pallaoro and Kovačić 2000) and in the Aegean Sea (Ahnelt and Dorda 2004). Thorogobius macrolepis is known from only a few records from the Adriatic Sea (Ahnelt and Kovačić 1997, Guidetti et al. 2006), from France and the Balearic Islands in the western Mediterranean (Ahnelt and Patzner 1996) and from the 
eastern Mediterranean at the southern Aegean Sea and eastern Levantine coasts (Francour et al. 2007).

The presently reported study applied bottom quadrats that produced quantitative data on fish bottom abundance and it introduced a safe, relatively simple, and efficient application of using trimix diving for collecting fishes on depths below the reach of compressed-air divers. However, $70-75 \mathrm{~m}$ is the operating limit for SCUBA diving with open circuit diving system trimix, considering the carrying limit of the volume of the tanks that can provide the needed diving time to perform tasks in this kind of biological research and collecting. For lower parts of the circalittoral zone i.e., bellow 70-75 m, quantitative research using diving and anaesthetics could be performed only using the complicated and expensive method of closed-circuit rebreather systems with trimix (Pyle 1999).

The applied method showed to be efficient on the mixed circalittoral bottoms, both on coralligenous cover over bedrock and on shell debris, enabling collecting of cryptobenthic fishes and small epibenthic fishes. Only other method for collecting small benthic fishes at circalittoral depths is specially designed beam trawl made to collect samples of epibenthic organisms (Kovačić et al. 2016). It has advantage of covering much larger area of circalittoral bottom than diving. However, the method is limited on flat and soft bottoms. It can also be used on flat maerl beds (Kovačić et al. 2016). In addition, the use of this net has risk of damaging small fragile specimens during dragging. Therefore, the diving method with anaesthetics or ichthyocides remains only method to collect cryptobenthic and small epibenthic fishes at coralligenous communities other than maerl beds and on other steep or rugose rocky and mixed circalittoral bottoms.

\section{ACKNOWLEDGEMENTS}

The authors thank Petar Kružić (Faculty of Science, University of Zagreb) and Andrej Jaklin (The Center for Marine Research (CMR) of the Ruđer Bošković Institute in Zagreb) for identification of algal and invertebrates species. Thanks also go to Eva Jakupčević and Stamatis Zogaris (Hellenic Centre for Marine Research) for proofreading the English and Stamatis Zogaris for critical review of the article. We are grateful to the ServiceScape for additional editing of English language of the revised manuscript.

\section{REFERENCES}

Ahnelt H., Dorda J. 2004. Gobioid fishes from the north eastern Atlantic and the Mediterranean: New records and rarely found species. Annalen des Naturhistorischen Museums in Wien 105 B: 5-19.

Ahnelt H., Kovačić M. 1997. A northern Adriatic population of Thorogobius macrolepis (Teleostei: Gobiidae). Cybium 21 (2): 149-162.

Ahnelt H., Patzner R.A. 1996. Kryptobenthische Meergrundeln von den Balearen (Westliches Mittelmeer) mit Anmerkungen zum Unterartstatus von Chronogobius zebratus levanticus Miller, 1971 (Pisces: Teleostei: Gobidae). Annalen des Naturhistorischen Museums in Wien 98 B: 529-544.
Bejarano I., Nemeth M., Appeldoorn R.S. 2010. Use of mixed-gas rebreathers to access fish assemblages in mesophotic coral ecosystems (MCE) off La Parguera shelf-edge, Puerto Rico. Pp. 130-133. In: Proceedings of the 63rd Annual Gulf and Caribbean Fisheries Institute Meeting, 1-5 November 2010, San Juan, Puerto Rico.

Brokovich E., Einbinder S., Shashar N., Kiflawi M., Kark S. 2008. Descending to the twilight-zone: Changes in coral reef fish assemblages along a depth gradient down to $65 \mathrm{~m}$. Marine Ecology Progress Series 371: 253-262.

DOI: $10.3354 /$ meps07591

Dennis G.D., Bright T.J. 1988. Reef fish assemblages on hard banks in the northwestern Gulf of Mexico. Bulletin of Marine Science 43 (2): 280-307.

Feitoza B.M., Rosa R.S., Rocha L.A. 2005. Ecology and zoogeography of deep-reef fishes in northeastern Brazil. Bulletin of Marin Science 76 (3): 725-742.

Francour P., Bilecenoglu M., Kaya M. 2007. In situ observations on new and rare gobies from the eastern Mediterranean Sea. Rapport Commission International pour l'exploration scientifique de la Mer Mediterranee 38: 478 .

Guidetti P., Bussotti S., Kovačić M. 2006. First record of the large-scaled goby, Thorogobius macrolepis (Pisces, Gobiidae), in Italian seas. Thalassia Salentina 29: 41-45.

Herler J., Patzner R.A., Sturmbauer C. 2005. A preliminary revision of the Gobius auratus species complex with redescription of Gobius auratus Risso, 1810. Journal of Natural History 39 (14): 1043-1075. DOI: $10.1080 / 00222930400001533$

Kovačić M., Ordines F., Schliewen U.K. 2016. A new species of Speleogobius (Teleostei: Gobiidae) from the western Mediterraenean Sea. Zootaxa 4066: 301-310. DOI: 10.11646/zootaxa.4066.3.6

Kovačić M., Patzner R.A., Schliewen U.K. 2012. A first quantitative assessment of the ecology of cryptobenthic fishes in the Mediterranean Sea. Marine Biology 159 (12): 2731-2742.

DOI: $10.1007 / \mathrm{s} 00227-012-2030-6$

Marinovic J., Ljubkovic M., Breskovic T., Gunjaca G., Obad A., Modun D., Bilopavlovic N., Tsikas D., Dujic Z. 2012. Effects of successive air and nitrox dives on human vascular function. European Journal of Applied Physiology 112 (6): 2131-2137.

Pallaoro A., Kovačić M. 2000. Vanneaugobius dollfusi Brownell, 1978 a rare fish new to the Adriatic Sea. Journal of Fish Biology 57 (1): 255-257. DOI: $10.1111 / \mathrm{j} .1095-8649.2000 . t b 00791 . x$

Pyle R.L. 1997. The importance of deep safety stops: Rethinking ascent patterns from decompression dives. Journal of the South Pacific Underwater Medicine Society 27 (2): 112-115.

Pyle R.L. 1998. [7] Use of advanced mixed-gas diving technology to explore the coral reef "twilight zone". Pp. 71-88. DOI: 10.1007/978-1-4899-0136-1_9. 
In: Tanacredi J.T., Loret J. (eds.). Ocean pulse: Thresher R.E., Colin P.L. 1986. Trophic structure, A critical diagnosis. Springer US, New York, NY, USA.

DOI: 10.1007/978-1-4899-0136-1

diversity and abundance of fishes of the deep reef (30-300 m) at Enewetak, Marshall Islands. Bulletin of Marine Science 38 (1): 253-272.

Pyle R.L. 1999. Mixed-gas, closed-circuit rebreather use for identification of new reef fish species from 200-500 fsw. Pp. 53-65. In: Hamilton R.W., Pence D.F., Kesling D.E. (eds.) Assessment and feasibility of technical diving operations for scientific exploration. American Academy of Underwater Sciences, Nahant, MA, USA.

Pyle R.L., Earle J.L., Greene B.D. 2008. Five new species of the damselfish genus Chromis (Perciformes: Labroidei: Pomacentridae) from deep coral reefs in the tropical western Pacific. Zootaxa 1671: 3-31.

Received: 10 November 2015 Accepted: 16 February 2016 Published electronically: 31 March 2016 Sterk W. 2006. Health and efficiency in trimix versus air breathing in compressed air workers. Undersea and Hyperbaric Medicine 33 (6): 419-427.

Zander C.D. 1986. Gobiidae. Pp. 1096-1112. In: Whitehead P.J.P., Bauchot M.-L., Hureau J.-C., Nielsen J., Tortonese E. (eds.). Fishes of the northeastern Atlantic and the Mediterranean, Vol. 3. UNESCO, Paris. 